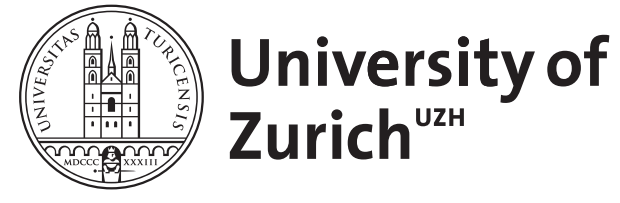

\title{
Winter huddling groups in the striped mouse.
}

\author{
Schradin, C ; Schubert, M ; Pillay, N
}

\begin{abstract}
Huddling is a strategy to avoid heat loss and thus save energy and is often observed in birds and rodents, which, because of their small body size, are prone to relatively high heat loss. Huddling might thus explain group-living in some cases, such as the winter huddling groups described for several northern hemisphere rodents. Here we describe winter huddling groups in an African rodent, the striped mouse (Rhabdomys pumilio (Sparrman, 1784)), from the Succulent Karoo of South Africa. Striped mice were radio-tracked and observed directly in the field. The importance of huddling in this species was demonstrated by comparing data collected over 2 years. The 2003 winter was characterized by a severe drought and $99 \%$ mortality. As a result, close kin were mainly unavailable and striped mice slept in non-kin huddling groups. In 2004, normal winter rainfall occurred, mortality was only 50\%, and striped mice formed family groups that shared a nest at night. While family groups were stable in 2004, non-kin huddling groups in 2003 were highly flexible and often changed from night to night. Huddling groups are important for striped mice to save energy, and the instability of non-kin sleeping groups indicates that the potential for conflict is higher between non-kin than between kin and that there is a trade-off between thermoregulatory requirements and kin selection.
\end{abstract}

DOI: https://doi.org/10.1139/Z06-048

Posted at the Zurich Open Repository and Archive, University of Zurich ZORA URL: https://doi.org/10.5167/uzh-573

Journal Article

Published Version

Originally published at:

Schradin, C; Schubert, M; Pillay, N (2006). Winter huddling groups in the striped mouse. Canadian Journal of Zoology, 84(5):693-698.

DOI: https://doi.org/10.1139/Z06-048 


\title{
Winter huddling groups in the striped mouse
}

\author{
C. Schradin, M. Schubert, and N. Pillay
}

\begin{abstract}
Huddling is a strategy to avoid heat loss and thus save energy and is often observed in birds and rodents, which, because of their small body size, are prone to relatively high heat loss. Huddling might thus explain group-living in some cases, such as the winter huddling groups described for several northern hemisphere rodents. Here we describe winter huddling groups in an African rodent, the striped mouse (Rhabdomys pumilio (Sparrman, 1784)), from the Succulent Karoo of South Africa. Striped mice were radio-tracked and observed directly in the field. The importance of huddling in this species was demonstrated by comparing data collected over 2 years. The 2003 winter was characterized by a severe drought and $99 \%$ mortality. As a result, close kin were mainly unavailable and striped mice slept in non-kin huddling groups. In 2004, normal winter rainfall occurred, mortality was only 50\%, and striped mice formed family groups that shared a nest at night. While family groups were stable in 2004, non-kin huddling groups in 2003 were highly flexible and often changed from night to night. Huddling groups are important for striped mice to save energy, and the instability of non-kin sleeping groups indicates that the potential for conflict is higher between non-kin than between kin and that there is a trade-off between thermoregulatory requirements and kin selection.
\end{abstract}

Résumé : L'entassement des individus est une stratégie pour éviter la perte de chaleur et ainsi sauver de l'énergie; il s'observe souvent chez les oiseaux et les rongeurs qui sont sujets à des pertes relativement élevées de chaleur à cause de leur petite taille corporelle. L'entassement peut ainsi peut-être expliquer le vie en groupes dans certains cas, comme par exemple les groupes d'entassement d'hiver décrits chez plusieurs rongeurs de l'hémisphère nord. Nous décrivons ici des groupes d'entassement d'hiver chez un rongeur africain, le rat rayé champêtre (Rhabdomys pumilio (Sparrman, 1784)) du Karoo à plantes succulentes de l'Afrique du Sud. Nous avons suivi les rats rayés à l'aide d'émetteurs radio et par observation directe en nature. La comparaison des données récoltées pendant 2 années montre l'importance de l'entassement chez cette espèce. L'hiver 2003 a été caractérisé par une forte sécheresse et une mortalité de $99 \%$. En conséquence, il y avait peu de proches parents disponibles et les rats rayés ont dormi dans des groupes d'entassement non constitués de parents. En 2004, il y a eu les pluies normales d'hiver et la mortalité a été seulement de $50 \%$; les rats rayés ont formé des groupes familiaux qui partageaient un même nid pour la nuit. Alors qu'en 2004 les groupes familiaux étaient stables, en 2003 les groupes d'entassement constitués d'animaux non apparentés étaient très flexibles et changeaient souvent d'une nuit à l'autre. Les groupes d'entassement sont d'importance pour les rats rayés pour sauver de l'énergie; l'instabilité des groupes de sommeil non apparentés laisse croire que la possibilité de conflits est plus grande dans les groupes non apparentés que dans les groupes familiaux et qu'il y a un compromis entre les besoins de thermorégulation et la sélection de parentèle.

[Traduit par la Rédaction]

\section{Introduction}

Group-living might arise when dispersal is constrained and (or) animals inhabit adverse habitats (Emlen 1995; Krause and Ruxton 2002). Group-living is likely to enable better survival and higher reproductive success, especially when the costs of group-living are low (Pulliam and Caraco 1984; Inman and Krebs 1987; Schradin 2000; Krause and Ruxton 2002). Group-living will be beneficial if it increases survival probability and reproductive success (e.g., by decreasing energy demands).

Energy is a limiting resource for many animals, and any

Received 17 October 2005. Accepted 7 March 2006. Published on the NRC Research Press Web site at http://cjz.nrc.ca on 1 June 2006.

C. Schradin, ${ }^{1,2}$ M. Schubert, and N. Pillay. School of Animal, Plant and Environmental Sciences, University of the

Witwatersrand, Johannesburg, South Africa.

${ }^{1}$ Present address: Zoological Institute, Department of Animal Behavior, University of Zurich, Winterthurerstrasse 190, 8057 Zurich, Switzerland.

${ }^{2}$ Corresponding author (e-mail: carsten@schradin.com). energy-saving mechanism is likely to be advantageous. This is especially the case when animals live in energy-restricted environments and when they use endogenous heat to maintain a constant body temperature. In small endotherms such as birds and rodents, huddling has evolved as one strategy for energy saving: several animals maintain close body contact, effectively reducing their surface area and decreasing heat loss to the environment (Canals et al. 1989). For example, in South Africa, the white-backed mousebird (Colius colius (L., 1766)) inhabits semidesert areas that are foodrestricted in winter, when night temperatures are often below zero (McKechnie et al. 2004). In winter, several mousebirds huddle together, which enables them to save up to $50 \%$ of their energy compared with solitary birds (McKechnie and Lovegrove 2001). Similarly, red-billed woodhoopoes (Phoeniculus purpureus (J.F. Miller, 1784)) from the dry sub-Saharan savannahs save up to $30 \%$ of daily energy expenditure by huddling, which might be one reason why this species shows cooperative breeding (BoixHinzen and Lovegrove 1998).

In Europe and North America, summers are moist, warm, and characterized by high food availability, while cold winters without plant growth are energy-restricted. Among 
northern hemisphere rodents, several species that are solitary during summer form huddling groups during winter (Webster and Brooks 1981; Madison et al. 1984; Wolton 1985), which probably functions to save energy (Contreras 1984; Andrews and Belknap 1986; Canals et al. 1998). Huddling might also be adaptive for species from the southern hemisphere, but documented evidence is rare. Huddling has been suggested to be important for degus (Octodon degus (Molina, 1782)) from South America (Ebensperger and Wallen 2002) and two rodent species from Australia (Bubela and Happold 1993; Tomlinson 2004).

Sleeping in groups has been described in the African striped mouse (Rhabdomys pumilio (Sparrman, 1784)) in the Succulent Karoo of South Africa, in both spring and summer (Schradin and Pillay 2004, 2005c). In the Succulent Karoo, the diurnal striped mouse (adult body mass 30-80 g) forms groups that typically consist of $2-4$ breeding females, 1 breeding male, and philopatric adult offspring of both sexes (Schradin and Pillay 2004). While groups share one nest and territory, they forage alone (Schradin 2006a), such that foraging benefits cannot explain group-living (Schradin 2006b). The Succulent Karoo is a semidesert characterized by rain in winter, a spring with maximal food abundance and a 3month-long breeding season, and a dry summer with limited food availability, when mice lose approximately $12 \%$ of their body mass (Schradin and Pillay 2005a). Night temperatures are often below zero in winter and can be as low as $5{ }^{\circ} \mathrm{C}$ in summer (measured at ground level, where mice nest; unpublished data). Sharing a nest might have two main advantages: increased vigilance and thus better predator avoidance during the night, and thermoregulatory benefits due to huddling (Schradin 2005b). Striped mice in larger groups have lower oxygen consumption, which is particularly important when ambient temperatures are low (Scantlebury et al. 2006). When groups of free-ranging striped mice are experimentally reduced, such that fewer individuals share a nest during the night, energy expenditure (measured using double-labelled water) and water consumption increase (Scantlebury et al. 2006).

Energy saving due to huddling could be an important reason for group-living in striped mice in the Succulent Karoo. However, all groups observed so far appear to consist of close kin that form extended families (Schradin and Pillay 2004). Thus, group-living could also be simply explained by (i) habitat saturation, which would reduce opportunities for mice to emigrate and establish their own groups and thus encourage them to stay at home, and (or) (ii) kin selection, which would favour communal nesting and group territoriality (Schradin 2005b). We predict that if huddling is a primary reason for group-living, (i) huddling groups will form even at low population densities (thus, group-living is not due to habitat saturation), and (ii) huddling groups will form between non-kin when close kin are not available (thus, sleeping groups cannot be explained by kin selection).

Here we present data on sleeping groups of striped mice for two winters, one with very low and one with high population density. These demographic differences were expected to lead to important differences in the formation of sleeping groups, since low population density decreases the likelihood of close kin being available. To save water and energy, striped mice should form huddling groups with unrelated in- dividuals when no close kin are available. We therefore predicted that stable family groups would form during the winter with high population density, but huddling groups of unrelated individuals would form during the winter with very low population density.

\section{Methods}

\section{Study area and period}

This study was conducted in Goegap Nature Reserve near Springbok in the Northern Cape province of South Africa from September 2002 to December 2002, July 2003 to January 2004, and May 2004 to December 2004. The vegetation type is Succulent Karoo (Cowling et al. 1999; Rösch 2001), comprising mainly Zygophyllum retrofractum (Thunb.) and Lycium cinerum (Thunb.) shrubs, and there are sandy areas occupied by annual succulents and by wild flowers in spring (see pictures at http://www.stripedmouse.com/site1_4.htm). Daily minimum and maximum temperatures were measured at the research station next to the field site.

Rainfall in Goegap is low, averaging $160 \mathrm{~mm} /$ year (Rösch 2001); an average of $194 \mathrm{~mm} /$ year was measured at a permanent weather station situated at Springbok, $20 \mathrm{~km}$ away from the study site. However, in 2003, only $32 \mathrm{~mm}$ of rain was recorded, making this the driest year since 1984. Importantly, only $5 \mathrm{~mm}$ of rain was recorded during the rainy season in winter (April to July 2003), resulting in the driest winter since 1960, when the weather station was established (average for April-July, $104 \mathrm{~mm}$; Springbok weather station). Accordingly, the area was very dry in August 2003, and no new green plant growth was apparent. The rains arrived only at the end of August $(102.8 \mathrm{~mm}$, the highest amount of rain for August since at least 1960), resulting in an onset of spring plant growth 2 months later than normal (i.e., in October). In the following autumn and winter, the rain pattern was normal and provided mice with sufficient food sources and a normal breeding season from the middle of August to November 2004.

The size of the field site was chosen in relation to population density. In 2002, the study area consisted of 1.3 ha, but this was increased to 36 ha in 2003 after high mortality during the drought (see Results). Since the population density increased after the drought, we decreased the field site to 9.5 ha in 2004 (Table 1).

\section{Trapping and marking of animals}

Striped mice were trapped using locally manufactured metal live-traps $(26 \mathrm{~cm} \times 9 \mathrm{~cm} \times 9 \mathrm{~cm})$ baited with a mixture of bran flakes, currants, sea salt, and salad oil. Traps were placed in the shade under shrubs, approximately every $20 \mathrm{~m}$. The locations of nests were established by radiotracking striped mice at night. Thereafter, traps were placed in the shade under bushes where mice were nesting. Trapping was done only in the morning and the afternoon, but not during the hottest times of the day. Traps were checked at least every $2 \mathrm{~h}$. Trapped mice were sexed and weighed and their reproductive status was determined. Mice were retrapped about every 4 weeks to refresh the markings and to mark juveniles and emigrants on the grid. To permanently mark mice, we used ear tags (National Band and Tag Company, Newport, Kentucky). 


\section{Determination of natal groups of mice}

For identification of individuals, each trapped mouse received a number written on its side with black hair dye (Rapido, Pinetown, South Africa; see Fig. $1 b$ in Schradin and Pillay 2004 or at http://www.stripedmouse.com). Group affiliation of individuals was determined by observing nests during mornings and afternoons and recording all individuals present at each nest. Striped mice are diurnal and typically bask in front of their nest in the morning before leaving for foraging and in the afternoon before withdrawing into the nest for the night (Schradin and Pillay 2004). Nest observations followed a standard protocol that we established at our field site: mice were observed from a distance of 5-10 $\mathrm{m}$ and were well habituated to the presence of observers (Schradin and Pillay 2004). Mice were regarded as being natal to a nest if they were trapped as juveniles at that nest and later observed regularly at that nest and no other nest. Adult males were regarded as having emigrated into a group if they were not previously trapped in that group and were subsequently observed regularly at the nest of that group.

\section{Radio-tracking}

Radio-tracking was performed using an AR8000 widerange receiver (AOR (UK) Ltd., Matlock, Derbyshire, UK) and an RA-14K antenna (Telonics, Inc., Mesa, Arizona). Individuals were equipped with $\mathrm{MD}-2 \mathrm{C}$ radiotransmitters (Holohil Systems Ltd., Carp, Ontario). Transmitters weighed $2.5 \mathrm{~g}$, including the collar, which represented less than $10 \%$ and often less than $5 \%$ of body mass. All radio-tracked mice were adults. We radio-tracked 14 females and 8 males in winter 2003 and 12 females and 10 males in winter 2004 (Table 1).

\section{Determination of sleeping sites and sleeping groups}

Composition of sleeping groups was determined in two ways. (1) Striped mice were radio-tracked at night, when they were inactive. Sleeping sites were recorded using a global positioning system (eTrex Venture, Garmin International Inc., Olathe, Kansas) and marked with a plastic flag in the field. (2) Direct observations of nests located by radio-tracking were performed during mornings and afternoons (see above and Schradin and Pillay 2004).

\section{Statistics and data analysis}

Striped mice were assigned to three categories based on their social organisation. (1) Solitary: individuals were alone in a nest more than $50 \%$ of the time. (2) Family or extended family: individuals originating from the same group shared a nest, but single males from other groups could also be present (males are the dispersing sex). (3) Non-kin huddling group: individuals originating from different groups shared a nest.

The minimum number of mice alive (presented as number of mice/ha) was determined as the number of mice trapped during month $x$ plus the number of mice not trapped during month $x$ but trapped in the same area during both the previous and the following months (indicating that they were present in month $x$ but not trapped). Data are given only for months for which trapping data are also available for the previous and following months.

Data are presented as means \pm SD. Nonparametric tests were applied throughout using the software InStat (GraphPad Software Inc., San Diego, California); all tests were two-
Table 1. Number of striped mice (Rhabdomys pumilio) present and radio-tracked at our study site during 2003 and 2004.

\begin{tabular}{lll}
\hline & August 2003 & August 2004 \\
\hline Study area & 36 ha & 9.5 ha \\
No. of mice at study area & $22(8 / 14)$ & $41(19 / 22)$ \\
No. of mice of known origin & $2(0 / 2)$ & $32(12 / 20)$ \\
No. of mice/ha & 0.6 & 4.3 \\
No. of mice radio-tracked & $22(8 / 14)$ & $22(10 / 12)$ \\
No. of nests/families observed & 8 & 9
\end{tabular}

Note: Numbers of males/females are in parentheses.

tailed. The Fisher's exact test is abbreviated as Fisher Test. The Kruskal-Wallis test followed by Dunn's post test (hereafter, Dunn Test) was used for selected comparisons.

\section{Results}

\section{Survival probability and population density}

Population densities and survival probabilities are given in Table 2. The proportion of mice that survived from 2002 to 2003 (2 of 207) was significantly lower than the proportion that survived from 2003 to 2004 (30 of 60; $p<0.0001$, Fisher Test). The minimum number alive was twice as high at the start of the 2004 breeding season as in 2003 .

The consequences of the dry season are apparent in changes in body mass. Body mass of adult males differed significantly over seasons $(p<0.0001, \mathrm{KW}=33.3$, KruskalWallis test). Mass of adult males was $62.5 \pm 9.3 \mathrm{~g}(n=13)$ at the start of the dry season in November 2002, decreased to $36.1 \pm 4.9 \mathrm{~g}(n=16)$ at the end of the dry season in August 2003 ( $p<0.001$, Dunn Test), increased to $58.1 \pm$ $11.9 \mathrm{~g}(n=7)$ at the start of the dry season in November 2003 ( $p<0.01$, Dunn Test), and decreased again to $38.5 \pm$ $7.7 \mathrm{~g}(n=26)$ at the end of the dry season in May 2004 ( $p<0.01$, Dunn test; note that the dry season ended several months earlier in 2004 than in 2003, when there was a drought). There was no difference in male body mass between the end of the 2003 dry season and the end of the 2004 dry season $(p>0.05)$.

Body mass of adult females differed significantly over seasons ( $p<0.0001, \mathrm{KW}=45.0$, Kruskal-Wallis test). Mass of adult females was $54.7 \pm 8.1 \mathrm{~g}(n=20)$ at the start of the dry season in November 2002, decreased to $33.0 \pm$ $4.0 \mathrm{~g}(n=21)$ at the end of the dry season in August 2003 $(p<0.001$, Dunn Test), increased to $54.4 \pm 12.1 \mathrm{~g}(n=11)$ at the start of the dry season in November $2003(p<0.001$, Dunn test), and decreased again to $34.3 \pm 6.8 \mathrm{~g}(n=29)$ at the end of the dry season in May $2004(p<0.001$, Dunn test). There was no difference in female body mass between the end of the 2003 dry season and the end of the 2004 dry season $(p>0.05)$.

\section{Composition of sleeping groups}

In August 2003, sleeping groups consisted of $2.8 \pm 2.4$ individuals (range $1-9, n=56$ sleeping group observations). In August 2004, sleeping groups consisted of $2.8 \pm 1.1$ individuals (range $1-4, n=9$ groups). There was no difference in group size between years ( $p=0.3, U=197$, Mann-Whitney $U$ test).

Owing to the extraordinarily low survival in 2003 
Table 2. Minimum number alive (MNA; number of mice/ha) for striped mice at the end and start of the breeding seasons as well as survival probability from the end of one breeding season to the next, for 2002/2003 and 2003/2004.

\begin{tabular}{lll}
\hline & $2002 / 2003$ & $2003 / 2004$ \\
\hline MNA, end of breeding season & 159.2 & 6.3 \\
MNA, start of breeding season & 1.5 & 3.2 \\
$\begin{array}{l}\text { Survival probability to next breeding } \\
\text { season }\end{array}$ & $1 \%$ & $50 \%$ \\
\hline
\end{tabular}

Note: In calculations, we included data only from areas that were trapped during both years ( 1.3 ha in $2002 / 2003$ and 9.6 ha in 2003/2004). For this reason, the data here differ from those in Table 1.

(Table 2), the sample size for females from known natal groups in winter 2003 was very low. In 2003, we knew the natal group of only two females (F43 and F117, both from natal group 4) because all other marked striped mice from the previous year had disappeared during the drought. These two females spent their nights in five different huddling groups, sometimes with each other and sometimes apart. They shared nests with a total of two other females, resulting in at least four females spending nights with unrelated females. In 2004, one radio-collared female had no surviving female kin and shared a nest with her brother. The remaining 11 radio-collared females shared nests only with related females that originated from the same natal group. Additionally, males from the same natal group and sometimes one male from another group slept in the same nest (breeding males emigrate from other groups). Additionally, nine females without radio-collars were known to sleep in their natal group. All females in winter 2003 shared nests with unrelated females, and no females did so in 2004 ( $p<$ 0.0001 , Fisher test).

In 2003, one radio-collared female always slept alone. All other 21 individuals slept in groups. Group compositions often changed from night to night as mice changed from one sleeping group to another (Fig. 1). In contrast, all 12 females radio-tracked in winter 2004 slept in their natal groups, and sleeping groups were stable (Fig. 1). Group composition was flexible in 2003 but more stable in 2004 ( $p<0.0001$, Fisher test). Sleeping group size in 2003 did not correlate with minimum night temperature ( $r_{\mathrm{S}}=-0.46, p>0.1, n=10$, Spearman's rank correlation) but correlated negatively with maximum day temperature $\left(r_{\mathrm{S}}=-0.65, p<0.05, n=10\right)$.

\section{Discussion}

The striped mouse is group-living in the arid Succulent Karoo, where population density is high, whereas it is solitary in grassland habitats, where population density is much lower (Schradin and Pillay 2005c). It has been suggested that in the Succulent Karoo, habitat saturation resulting from high population density might limit natal dispersal and force philopatry, thus leading to group-living (Schradin and Pillay 2005c; Schradin 2005b). However, while habitat saturation might indeed constrain dispersal, this alone cannot explain group-living. During the present study, mice formed sleeping groups at population densities as low as 1.5 mice/ ha (in 2003), while mice are solitary in grassland habitats at a population density of 10-40 mice/ha (Perrin et al. 2001;
Schradin and Pillay 2005c). Therefore, there are most likely benefits to group-living in the Succulent Karoo that are absent or less apparent in the grasslands.

Night temperatures are lower in the Succulent Karoo than in grasslands (Schradin and Pillay 2005b). In the Succulent Karoo, the presence of the father has a positive influence on pup development, probably by warming pups during cold winter nights, which is not the case in the warmer grasslands (Schradin and Pillay 2005b). Thus, the benefits of alloparental care might be one explanation for group-living in the Succulent Karoo. However, huddling groups would benefit not only pups, as adults could also reduce heat loss and energy expenditure (Contreras 1984; Andrews and Belknap 1986; Canals et al. 1989; Canals et al. 1998). Huddling in the striped mouse does reduce energy expenditure, especially during cold nights (Scantlebury et al. 2006). In our study population, sleeping in a huddling group reduced daily energy expenditure by $20 \%$, and huddling is accompanied by a significant reduction in water consumption, which is an important consideration in a desert-dwelling mammal (Scantlebury et al. 2006). Winter huddling groups have been reported in northern hemisphere rodents (Webster and Brooks 1981; Madison et al. 1984; Wolton 1985) but, to our knowledge, this is the first study to report winter huddling groups of non-kin in an African rodent species.

In meadow voles (Microtus pennsylvanicus (Ord, 1815)), winter huddling groups initially comprise families but change to groups of unrelated individuals during the winter as population density declines and fewer kin are present (Webster and Brooks 1981; Madison et al. 1984). Similarly, striped mice lived in family groups in December (summer) 2002 (Schradin and Pillay 2004) but in groups of unrelated individuals at the end of the drought in August 2003. The Succulent Karoo experienced a severe drought in winter 2003, leading to extremely low food abundance and resulting in the local extinction of some species (e.g., bush Karoo rat, Otomys unisulcatus F. Cuvier, 1829; Schradin 2005a). Striped mice experienced substantial mass loss during the drought, and mortality during winter was 99\%, compared with 50\%-73\% in good years (Schradin and Pillay 2005a; this study). In the absence of kin, striped mice formed nonkin huddling groups, most likely to decrease energy expenditure. Similar results have been found in the normally solitary marsupial Phascogale tapoatafa (F. Meyer, 1793), which formed huddling groups of unrelated females only during a drought year (Rhind 2003).

Because of the survival probability of only $1 \%$ in 2003, we knew the origin of only two females. These females shared groups with two other females, resulting in at least four females sharing groups with non-kin. While our sample size is very low, we feel that these data, collected during an unusually severe drought, are especially interesting, as such rare events could shape the evolution of striped mice even more than ecological circumstances during normal years. The drought therefore offered a unique opportunity to conduct natural experiments of social behaviour. Our interpretation that sleeping groups differed between 2003 and 2004 is supported by the fact that sleeping groups were flexible in 2003 but stable in 2004.

The formation of non-kin huddling groups is unlikely to be the best option for striped mice for three reasons. (1) 
Fig. 1. Number of striped mice (Rhabdomys pumilio) in four different nests during 5 consecutive days in (a) August 2003 and (b) August 2004.
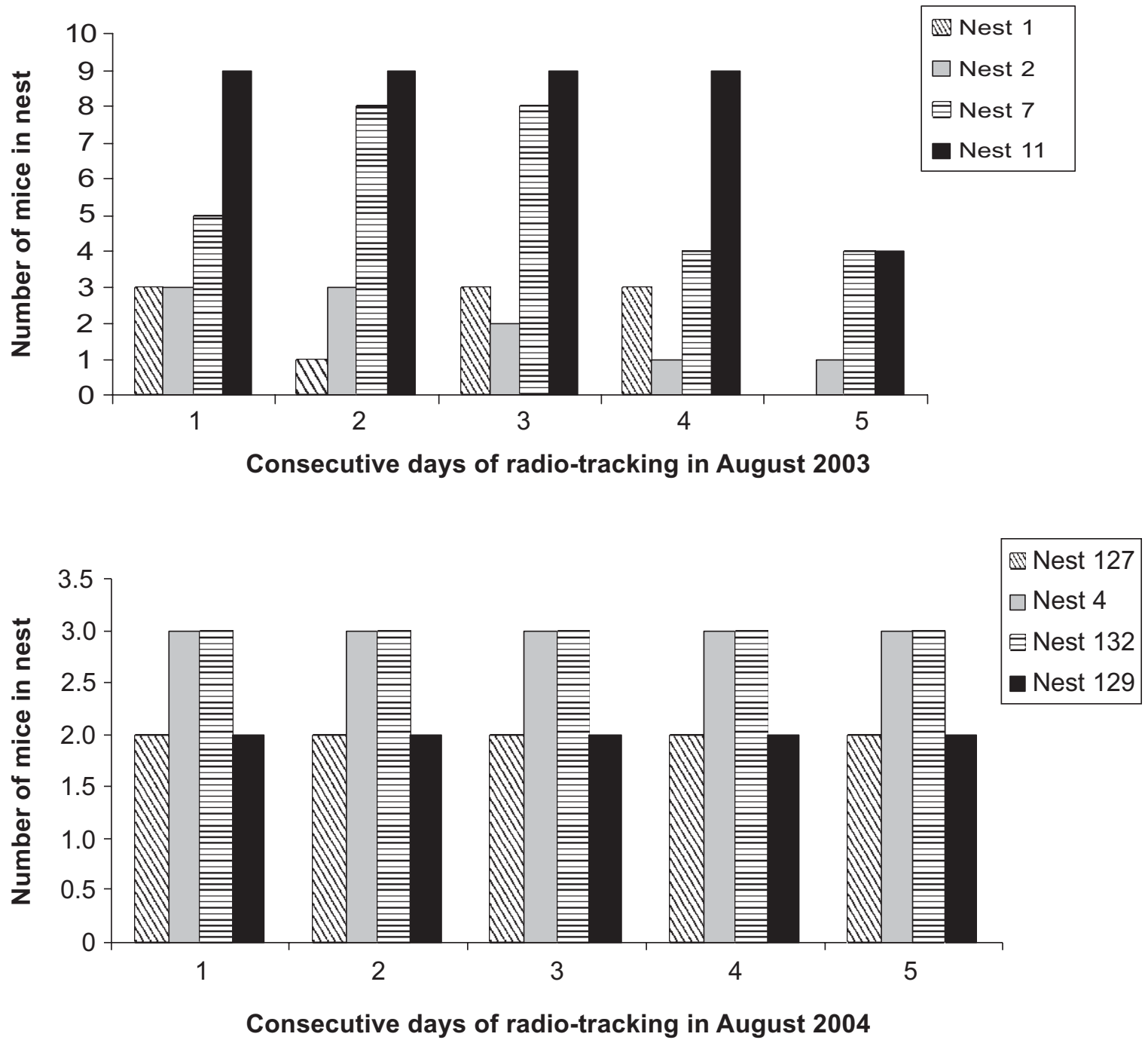

Striped mice normally react highly aggressively towards strangers but amicably towards group members (Schradin 2004, 2006; Schradin and Pillay 2004). (2) In 2004, when kin were available, mice slept in stable family groups and never with non-kin (apart from the breeding male that emigrated). (3) Non-kin huddling groups were not stable, and their composition often changed from night to night, resulting in individuals sleeping in different huddling groups. While the average size of non-kin groups in 2003 was similar to the size of family groups in 2004, the range in size was much higher in 2003. This was because much larger sleeping groups occurred in 2003 (up to 9 mice) than in 2004 (up to 4 mice), although population density in 2003 was only half that in 2004.

The reasons for the dynamic nature of sleeping groups in 2003 are unknown. Mice did not form larger sleeping groups when night temperatures were low. However, they formed larger sleeping groups when day temperatures were low. Perhaps mice used day temperatures to predict night temperatures. As the statistical power of our analyses was very low, the proximate reasons for the changing composition of non-kin sleeping groups remain speculative. How- ever, avoidance of non-kin and unfamiliar mice is very likely one of the main reasons.

Flexibility in the social system of the striped mouse occurs not only between the grassland and Succulent Karoo populations (Schradin and Pillay 2005c) but also within the Succulent Karoo population. The importance of huddling groups for minimizing energy loss might explain group-living in the striped mouse and can explain why in the absence of close kin even unrelated individuals share a nest at night. However, the instability of non-kin sleeping groups indicates that the potential for conflict is higher between non-kin than between kin, suggesting that non-kin sleeping groups may represent a trade-off between thermoregulatory requirements and kin selection.

\section{Acknowledgements}

We thank the Northern Cape Department of Tourism, Environment and Conservation for their assistance, and the staff at Goegap Nature Reserve for their support. We are grateful for field assistance provided by Brigitte Britz, Michaela Fürst, Christina Keller, Carola Schneider, Madeleine Scriba, 
and Philip Wiedmann. All parts of this study were approved by the animal ethics committee of the University of the Witwatersrand (AESC 2002-14-3, 2002-23-3). We are grateful to G. Anzenberger for support. This study was supported by the University of the Witwatersrand, the National Research Foundation (N.P., grant No. 2053514), the Fonds zur Förderung des akademischen Nachwuchses of the University of Zurich (C.S.), the German Science Foundation (C.S.), the Claude Leon Harris Foundation (C.S.), and the Deutscher Akademischer Austauschdienst (M.S.).

\section{References}

Andrews, R.V., and Belknap, R.W. 1986. Bioenergetic benefits of huddling by deer mice (Peromyscus maniculatus). Comp. Biochem. Physiol. A, 85: 775-778. doi:10.1016/0300-9629(86) 90294-X. PMID: 2879682.

Boix-Hinzen, C., and Lovegrove, B.G. 1998. Circadian metabolic and thermoregulatory patterns of red-billed woodhoopoes (Phoeniculus purpureus): the influence of huddling. J. Zool. (Lond.) 244: 33-41.

Bubela, T.M., and Happold, D.C.D. 1993. The social organisation and mating system of an Australian subalpine rodent, the broadtoothed rat, Mastacomys fuscus Thomas. Wildl. Res. 20: 405417. doi:10.1071/WR9930405.

Canals, M., Rosenmann, M., and Bozinovic, F. 1989. Energetics and geometry of huddling in small mammals. J. Theor. Biol. 141: 181-189. PMID: 2632987.

Canals, M., Rosemann, M., Novoa, F.F., and Bozinovic, F. 1998. Modulating factors of the energetic effectiveness of huddling in small mammals. Acta Theriol. 43: 337-348.

Contreras, L.C. 1984. Bioenergetics of huddling: test of a psychophysiological hypothesis. J. Mammal. 65: 256-262.

Cowling, R.M., Esler, J.J., and Rundel, P.W. 1999. Namaqualand, South Africa - an overview of a unique winter-rainfall desert ecosystem. Plant Ecol. 142: 3-21. doi:10.1023/A:1009831308074.

Ebensperger, L.A., and Wallen, P.K. 2002. Grouping increases the ability of the social rodent, Octodon degus, to detect predators when using exposed microhabitats. Oikos, 98: 491-497. doi:10. 1034/j.1600-0706.2002.980313.x.

Emlen, S.T. 1995. An evolutionary theory of the family. Proc. Natl. Acad. Sci. U.S.A. 92: 8092-8099. PMID: 7667250.

Inman, A.J., and Krebs, J. 1987. Predation and group-living. Trends Ecol. Evol. 2: 31-32. doi:10.1016/0169-5347(87)90093-0.

Krause, J., and Ruxton, G.D. 2002. Living in groups. Oxford University Press, Oxford.

Madison, D.M., FitzGerald, R.W., and McShea, W.J. 1984. Dynamics of social nesting in overwintering meadow voles (Microtus pennsylvanicus): possible consequences for population cycling. Behav. Ecol. Sociobiol. 15: 9-17. doi:10.1007/BF00310209.

McKechnie, A.E., and Lovegrove, B.G. 2001. Thermoregulation and the energetic significance of clustering behavior in the white-backed mousebird (Colius colius). Physiol. Biochem. Zool. 74: 238-249. doi:10.1086/319669. PMID: 11247743.

McKechnie, A.E., Körtner, G., and Lovegrove, B.G. 2004. Restphase thermoregulation in free-ranging white-backed mousebirds. Condor, 106: 143-149.

Perrin, M.R., Ercoli, C., and Dempster, E.R. 2001. The role of agonistic behaviour in the population of two syntopic African grassland rodents, the striped mouse Rhabdomys pumilio (Sparrman
1784) and the multimammate mouse Mastomys natalensis (A. Smith 1834) (Mammalia Rodentia). Trop. Zool. 14: 7-29.

Pulliam, H.R., and Caraco, T. 1984. Living in groups: is there an optimal group size? In Behavioural ecology: an evolutionary approach. Edited by J.R. Krebs and N.B. Davies. Blackwell Scientific Publications, Oxford. pp. 122-147.

Rhind, S.G. 2003. Communal nesting in the usually solitary marsupial, Phascogale tapoatafa. J. Zool. (Lond.) 261: 345-351.

Rösch, H. 2001. The identification and description of the management units of the Goegap Nature Reserve. Koedoe, 44: 17-30.

Scantlebury, M., Pillay, N., Speakman, J.R., Bennett, N.C., and Schradin, C. 2006. The energetics of huddling in group-living African four-striped field mice Rhabdomys pumilio. Funct. Ecol. 20: 166-173. doi:10.1111/j.1365-2435.2006.01074.x.

Schradin, C. 2000. Confusion effect in a reptilian and a primate predator. Ethology, 106: 691-700. doi:10.1046/j.1439-0310. 2000.00582.x.

Schradin, C. 2004. Territorial defense in a group-living solitary forager: who, where, against whom? Behav. Ecol. Sociobiol. 55: 439-446. doi:10.1007/s00265-003-0733-x.

Schradin, C. 2005a. Nest site competition in two diurnal rodents from the succulent karoo of South Africa. J. Mammal. 86: 757765. doi:10.1644/1545-1542(2005)086[0757:NCITDR]2.0.CO;2.

Schradin, C. $2005 b$. When to live alone and when to live in groups: ecological determinants of sociality in the African striped mouse (Rhabdomys pumilio, Sparrman, 1784). Belg. J. Zool. In press.

Schradin, C. 2006a. Whole day follows of the striped mouse. J. Ethol. 24: 37-43. doi:10.1007/s10164-005-0158-2.

Schradin, C. 2006 b. No information transfer of food sites in a group-living solitary forager. J. Ethol. In press.

Schradin, C., and Pillay, N. 2004. The striped mouse (Rhabdomys pumilio) from the succulent karoo of South Africa: a territorial group-living solitary forager with communal breeding and helpers at the nest. J. Comp. Psychol. 118: 37-47. doi:10.1037/07357036.118.1.37. PMID: 15008671.

Schradin, C., and Pillay, N. 2005a. Demography of the striped mouse (Rhabdomys pumilio) in the succulent karoo. Mamm. Biol. 70: 84-92.

Schradin, C., and Pillay, N. 2005b. The influence of the father on offspring development in the striped mouse. Behav. Ecol. 16: 450-455.

Schradin, C., and Pillay, N. 2005c. Intraspecific variation in the spatial and social organization of the African striped mouse. J. Mammal. 86: 99-107. doi:10.1644/1545-1542(2005) 086<0099:IVITSA>2.0.CO;2.

Schubert, M. 2005. Female reproductive strategies in the striped mouse (Rhabdomys pumilio): communal versus singular breeders. Diploma thesis, University of Bayreuth, Bayreuth, Germany. Available from www.stripedmouse.com/pdfe/diplomarbeit_melanie_schubert. pdf.

Tomlinson, S. 2004. Compareative metabolic physiology of Australian rodents: is behaviour more adaptive than torpor? Honours thesis, University of Western Australia, Perth, Australia.

Webster, A.B., and Brooks, R.J. 1981. Social behavior of Microtus pennsylvanicus in relation to seasonal changes in demography. $\mathrm{J}$. Mammal. 62: 738-751.

Wolton, R.J. 1985. The ranging and nesting behaviour of wood mice, Apodemus sylvaticus (Rodentia: Muridae), as revealed by radio-tracking. J. Zool. Ser. A, 206: 203-224. 